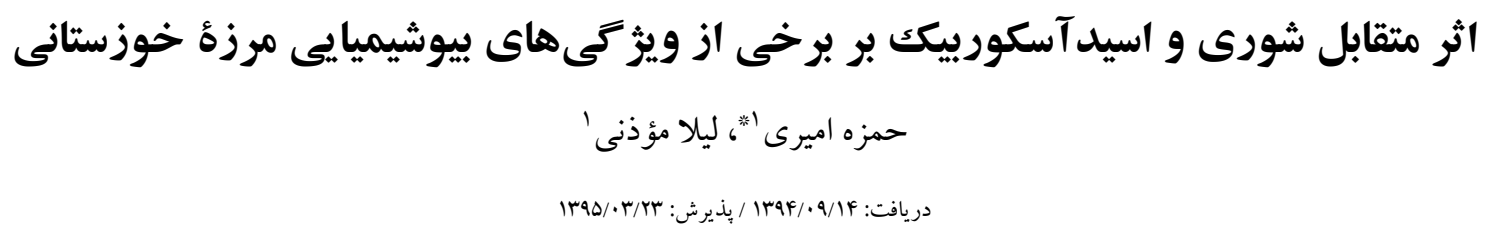

ايخروه زيستشناسى، دانشگاه لرستان، خرم باد، ايران amiri_h_lu@yahoo.com :مسئول مكاتبات"

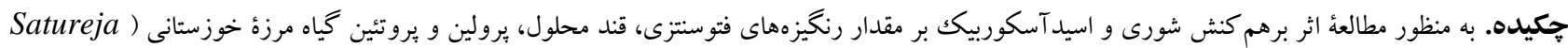
Na khuzestanica

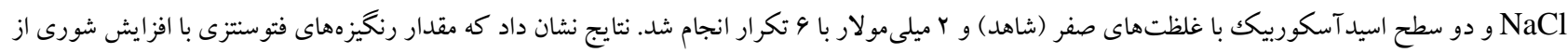

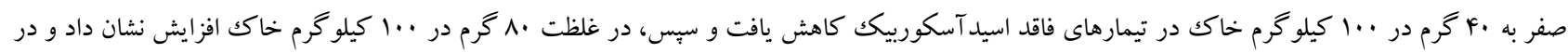

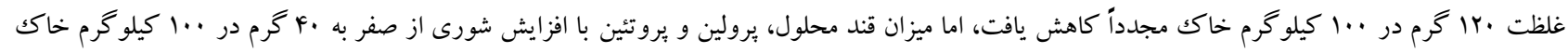

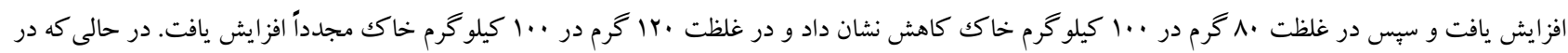

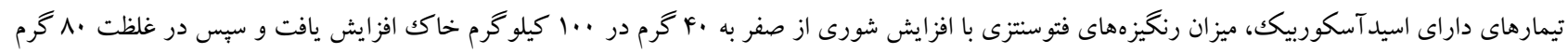

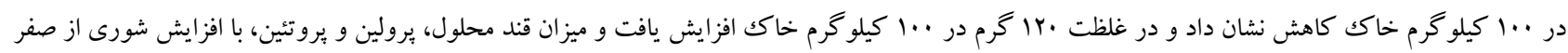

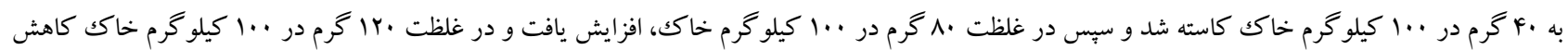

$$
\text { وازههاى كليدى. تنش شورى، ويتامين، بروتئين، برولين، كلروفيل }
$$

\title{
Interaction of salinity and ascorbic acid with some biochemical features in Satureja khuzestanica
}

\author{
Hamzeh Amiri ${ }^{* 1}$, Leila Moazzeni ${ }^{1}$ \\ Received: 04/12/2015 / Accepted: 12/06/2016
}

${ }^{1}$ Department of Biology, Lorestan University, Khorram-abad, Iran

*Correspondent author: amiri_h_lu@yahoo.com

\begin{abstract}
In order to study the interactive effects of salinity and ascorbic acid with the quantity of photosynthetic pigments, soluble sugar, proline and protein in Satureja khuzestanica plant, a factorial experiment was conducted in a completely randomized design (salinity at four levels of $0,40,80$ and $120 \mathrm{~g}$ in $100 \mathrm{~kg}$ soil and ascorbic acid at two levels of 0 and $2 \mathrm{mM}$ ) with 6 replicates. The results showed that photosynthetic pigments amount was decreased by the increase of the soil salinity from 0 to $40 \mathrm{~g} \mathrm{NaCl}$ in $100 \mathrm{~kg}$ soil, then increased by the salinity level of $80 \mathrm{~g} \mathrm{NaCl} \mathrm{in} 100 \mathrm{~kg}$ soil and then decreased by the salinity level of $120 \mathrm{~g} \mathrm{NaCl}$ in $100 \mathrm{~kg}$ soil again. The amount of soluble sugar, proline and protein was increased by the soil salinity levels of 0 to $40 \mathrm{~g}$ in $100 \mathrm{~kg}$ soil and then decreased by the salinity level of $80 \mathrm{gNaCl}$ in $100 \mathrm{~kg}$ soil, and showed an increase at the salinity level of $120 \mathrm{~g} \mathrm{NaCl}$ in $100 \mathrm{~kg}$ soil. In the presence of ascorbic acid, the amount of photosynthetic pigments was increased by the increase of the soil salinity from 0 to $40 \mathrm{~g}$ $\mathrm{NaCl}$ in $100 \mathrm{~kg}$ soil and then decreased by the salinity level of $80 \mathrm{~g} \mathrm{NaCl}$ in $100 \mathrm{~kg}$ soil and then increased by the salinity level of $120 \mathrm{~g} \mathrm{NaCl}$ in $100 \mathrm{~kg}$ soil. However, the quantity of soluble sugar, proline and protein was decreased by the increase of salinity level from 0 to $40 \mathrm{~g}$ in $100 \mathrm{~kg}$ soil, then increased by the salinity level of $80 \mathrm{~g} \mathrm{NaCl}$ in $100 \mathrm{~kg}$ soil, and finally decreased by the salinity level of $120 \mathrm{~g} \mathrm{NaCl}$ in $100 \mathrm{~kg}$ soil.
\end{abstract}

Keywords. salt stress, vitamin, protein, proline, chlorophyll 
هاى مختلف فيزيولوزيكى و بيوشيميايى وجود دارد، ازجمله

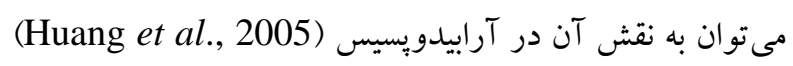

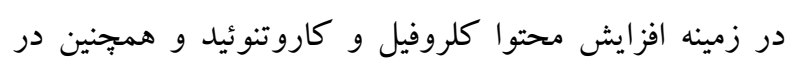

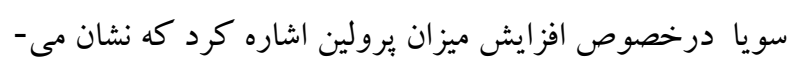

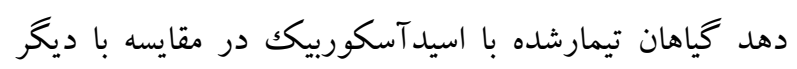

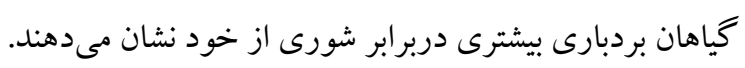
مرزه خوزستانى (Satureja khuzestanica Jamzad) متعلق

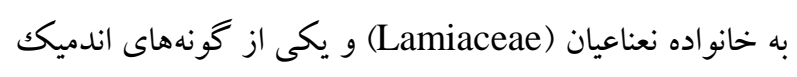

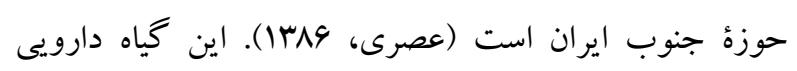

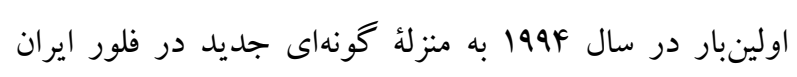

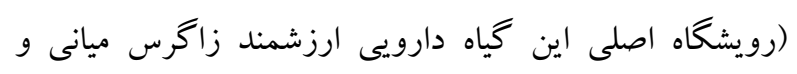
مناطق جنوب لرستان، شرق ايلام و شمال خوزستان است)

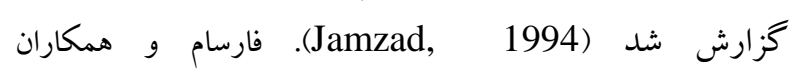
كارواكرول را تركيب اصلى اسانس مرزه خوزستانى (Y...F) گززارش كردند. اسانس هاى محتوى كارواكرول داراى فعاليت

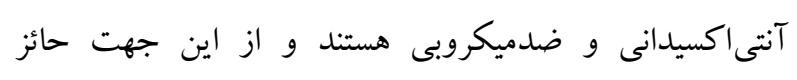

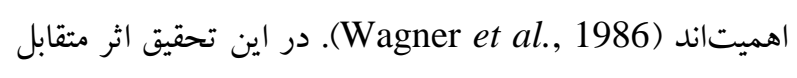
شورى و اسيدآسكوربيكك بر گياه مرزه خوزستانى بهمنظور تخفيف اثر تنش شورى بررسى شده است.

\section{مواد و روشها}

بهمنظور بررسى تغييرات ميزان رنخيزهها، برولين، قندهاى محلول

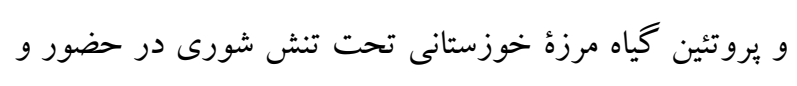

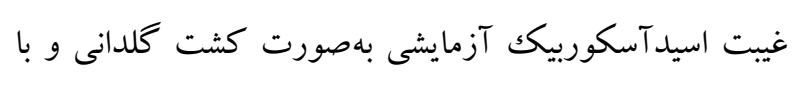

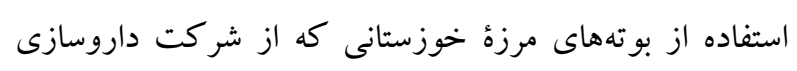

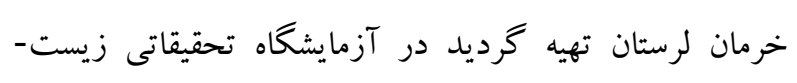

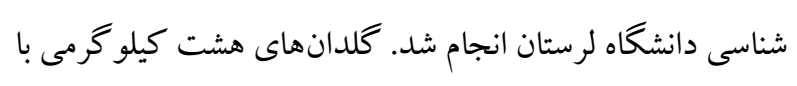

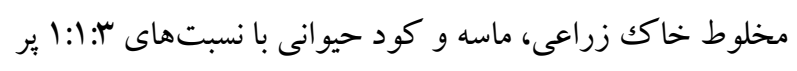
شد. آزمايش بهصورت فاكتوريل درقالب طرحسى ماعى كاملاً

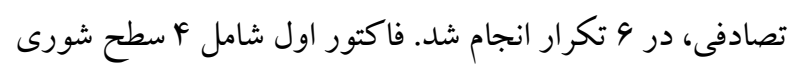

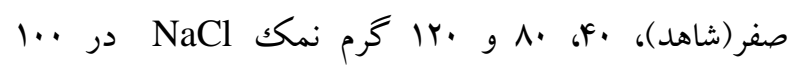

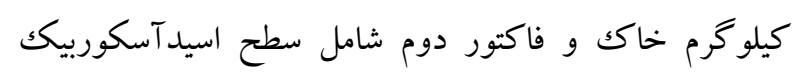

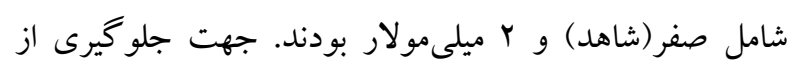
اعمال تنشهاى شورى شديد و ناخهانى به گياهان تحت تيمار،

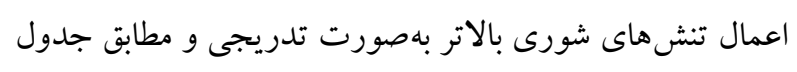

مقدمه

طيف وسيعى از تنشهاى محيطى، ماند افزايش يا كاهش دما،

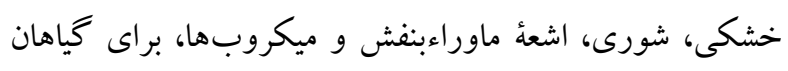

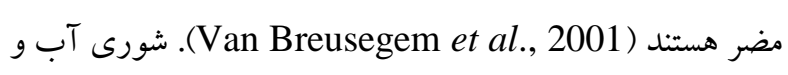
خاكك يكى از مشكلات جدى در كشاورزى است. كمبود منابع

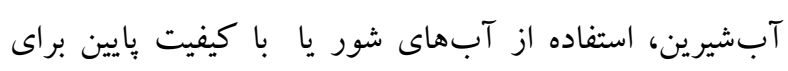

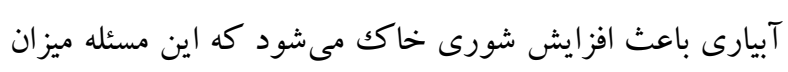

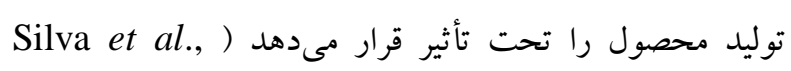

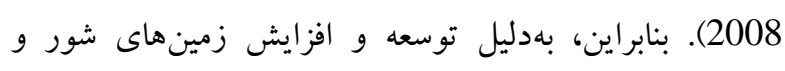
كاهش زمين كشاورزى مطلوب براى كشت، شناسايى گياهان

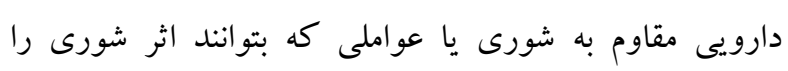
كاهش دهند اهميت زيادى دارد. باسخ خياهان به افزايش شورى باري

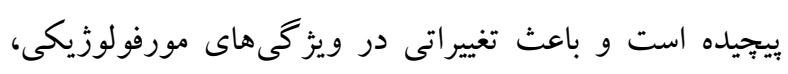
فيزيولوزيكى و متابوليسم گياه مىشود ( Parida \& Das, (2005 شورى ناشى از سديمكلرايد از رايجترين انواع شورى در خاككهاى زراعى ايران است كه قابليت توليد بسيارى از خياهان

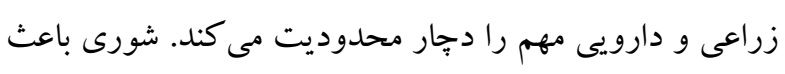

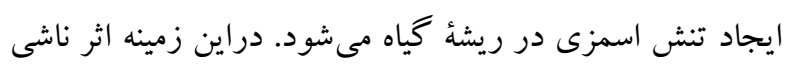

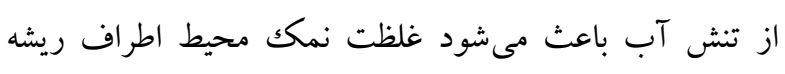
بيشتر از غلظت نمكك درون ريشه شود و بثرمردكى و نهايتاً كاهش شادابى و رشد را بهدنبال دارد (Munns et al., 2006).

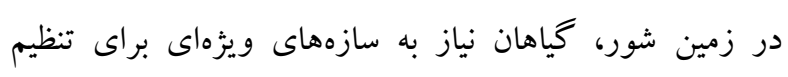
وضعيت اسمزى داخلى و تغيير فشار در محيط ريشه دارند.

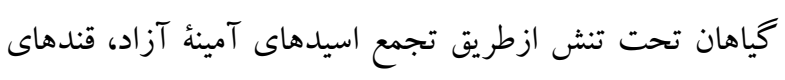

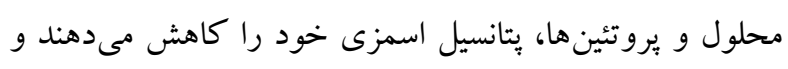

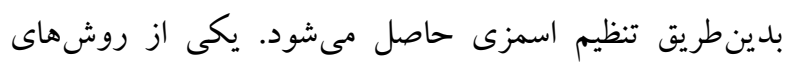

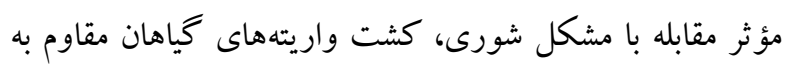

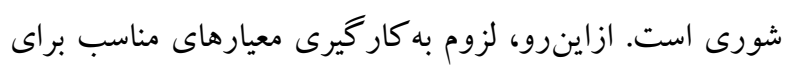

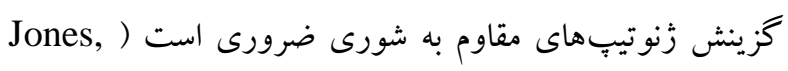
(1983

اسيد آسكوربيكك مولكول كوجگك فراوانى در گياهان و مادهاى كليدى در شبكة آنتىاكسيدانى شامل آسكوربات، كلوتاتيون،

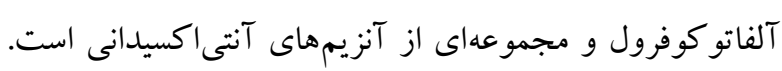

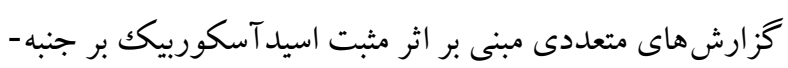


نظر به گَاهان تحت تيمار اضافه شد. ا انجام شد. NaCl مورداستفاده براى اعمال تنشها ابتدا در آب آبيارى بهصورت كامل حل شد و هفتهاى يككبار به ميزان مورد
جدول ا-برنامه هفتخى اعمال تيمارهاى شورى

Table 1. Weekly program of administration salinity treatment

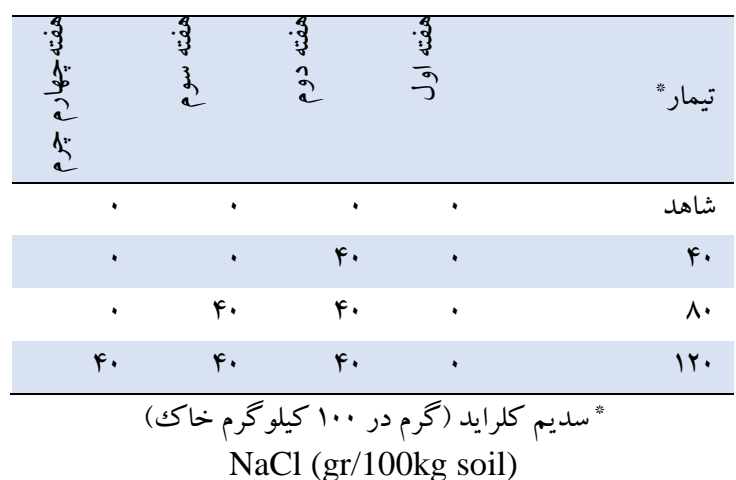

$\mathrm{NaCl}$ (gr/100kg soil) b كلروفيل= $=\frac{[(22.9 \times D 645)-(4.93 \times D 663)] \times V}{1000 \times W}$

\section{روش استخراج و سنجش قند محلول}

سنجش قند محلول اندام هوايى به روش كوجرت (I9NV) انجام شد. بدينصورت كه // • گرم از نمونها در الكل •V درصد بهمدت يككهفته قرار داده شد؛ سيس ا ميلىليتر از محلول رويى برداشته و به آن ا ميلىليتر فنل ه درصد و ه ميلىليتر اسيدسولفوريكك غليظ اضافه شد و يساز نيمساعت جذب نورى آنها در طول موج \&ND نانومتر بهوسيله اسيكتروفتومتر خوانده شد. رسم منحنى استاندارد با استفاده از كلوكز و تعيين ميزان قند برحسب گرم در هر گرم وزن خشك نمونه ها محاسبه شد.

\section{روش استخراج و سنجش يروتئين}

سنجش بروتئين به روش لاورى و همكاران (1901) صورت كرفت. براى سنجش ميزان يروتئين مراحل كار بهاينترتيب بود: همگگسازى نمونها در بافر ا مولار تريساسيد كلريدريك، سانتريفوز كردن نمونها، تهية معرفهاى A (كربناتسديم و سود ه/ نرمال)، B (سولفات مس ا درصد)، C (تارتاراتسديم-يتاسيم Y درصد)، D (شامل معرفهاى A و B و C)،

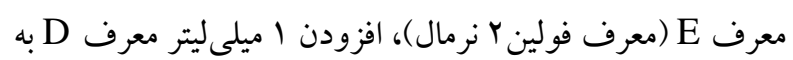

تيمار اسيدآسكوربيك همزمان با اجراى هفتخى تيمار شورى

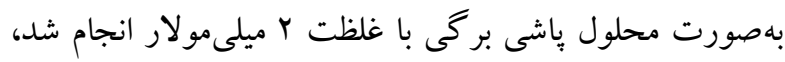

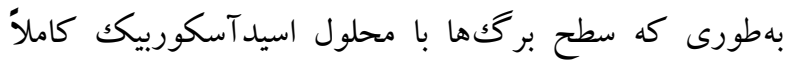

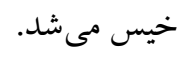

\section{روش استخراج رنغيزهها}

اندازه گيرى ميزان كلروفيل و كاروتنوئيدها در بركههاى مرزهة

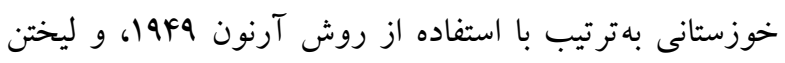

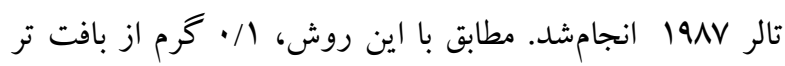

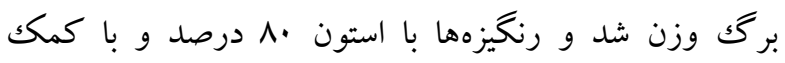

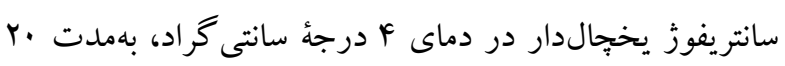

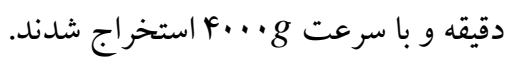

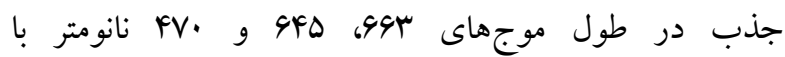
اسبكتروفتومتر (مدل

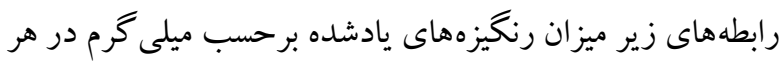

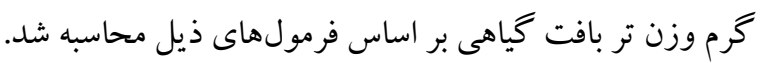

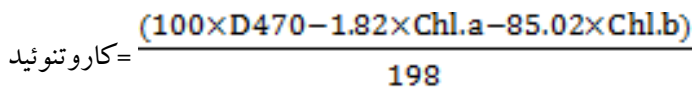

$$
\begin{aligned}
& \text { =W = }
\end{aligned}
$$

$$
\begin{aligned}
& \text { كل }=\frac{[(20.2 \times D 645)+(8.02 \times D 663)] \times V}{1000 \times W} \\
& \text { a كلروفيل= }=\frac{[(12.7 \times D \text { 663) }-(2.69 \times D 645)] \times V}{1000 \times W}
\end{aligned}
$$




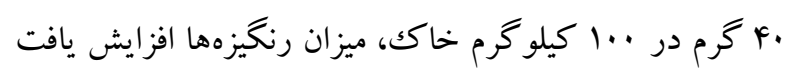

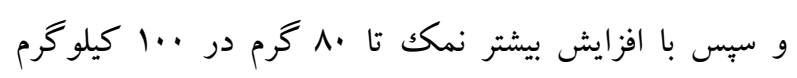

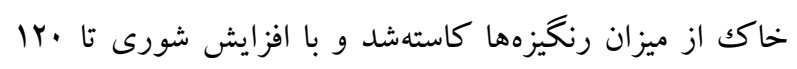

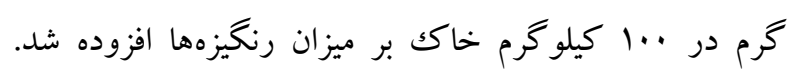

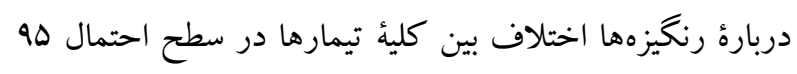

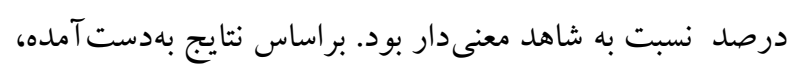

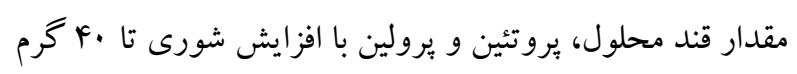

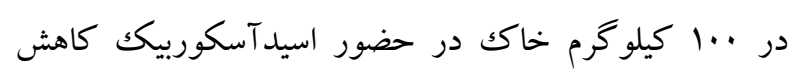

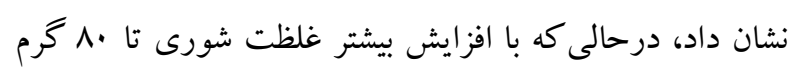

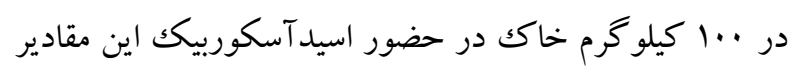

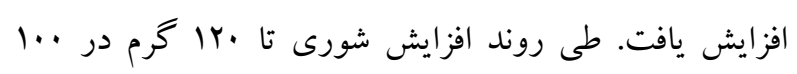

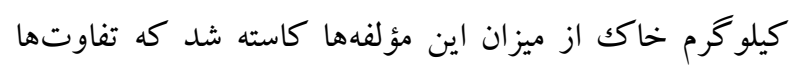

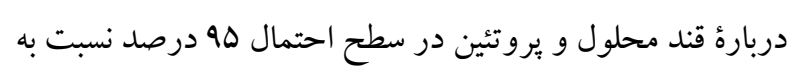

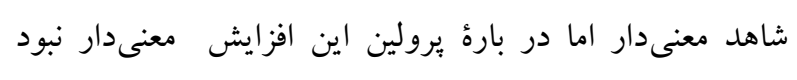

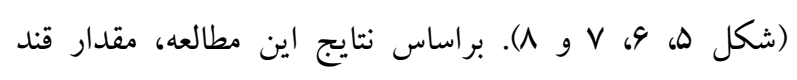

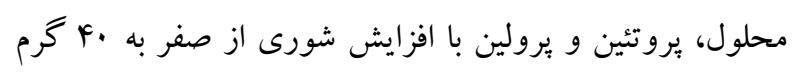

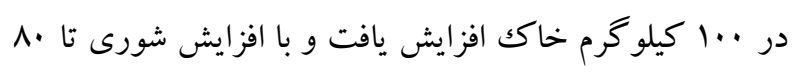

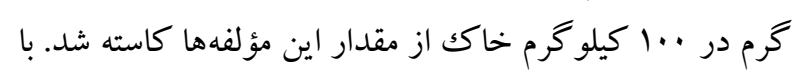

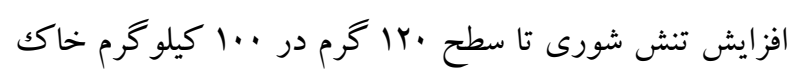

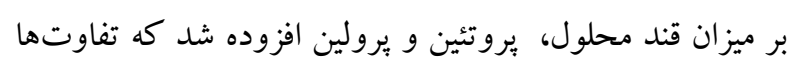

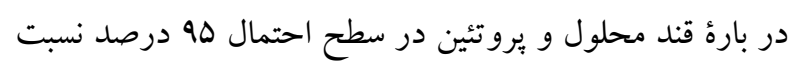

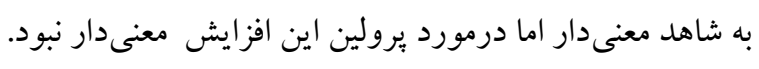

\section{بحث}

يافتهاى اين مطالعه نشان مىدهد كه در غلظت شورى •^ گرم

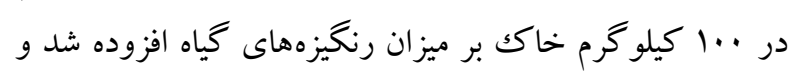

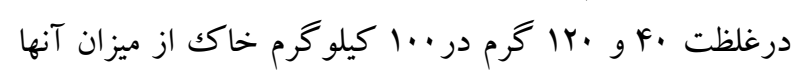

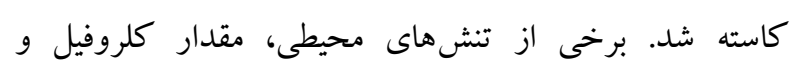
محصول را كاهش مىدهند و اين كاهش بستخى به زنوتيب كياه دارد (Colom \& Vazzana, 2001). اكبرى و همكاران نشان دادند كه در مرزه تابستانى (Satureja hortensis)، ميزان

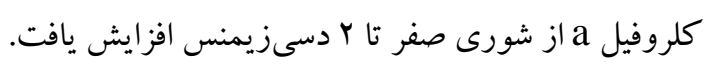

نمونه، اضافه كردن ب ميلى ليتر معرف E، خواندن جذب نمونهها در طول موج •VD نانومتر درمقابل شاهد. درنهايت، منحنى

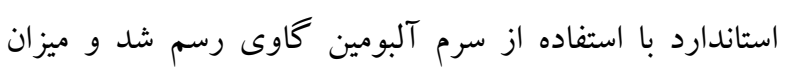
يروتئين برحسب گرم در گرم وزن تر گياه محاسبه شد.

\section{روش استخر اج و سنجش ثيرولين}

براى تعيين ميزان يرولين با روش بيتس و همكاران (19Vr) اين

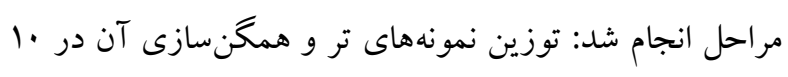

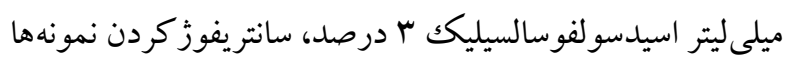

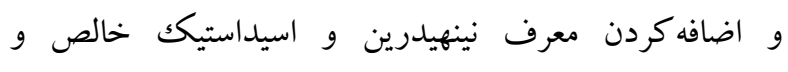

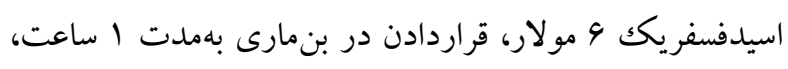

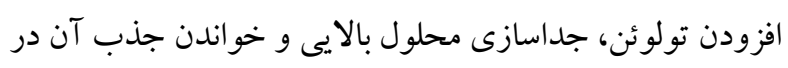
طول موج •مله نانومتر درمقابل شاهد. دريايان منحنى استاندارد

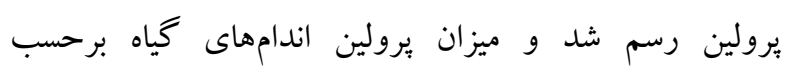
ميكرومول بر گرم وزن تر نمونه محاسبه شد.

\section{تجزيه و تحليل آمارى}

مقايسٔ ميانكين دادهها به وسيلة آزمون دانكن و با استفاده از نرم-

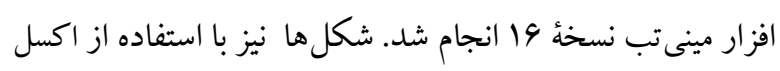
رسم شد.

نتايج نتايج يزووهش حاضر نشان داد كه با افزايش تنش شورى از صفر

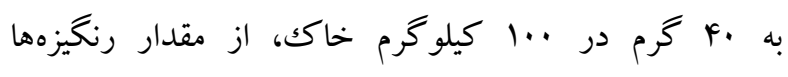

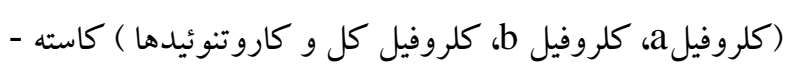

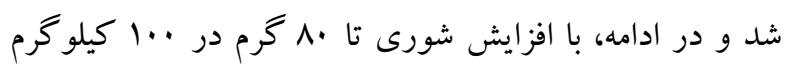

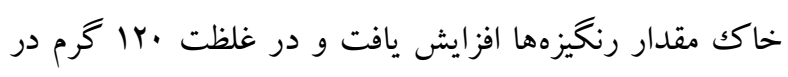

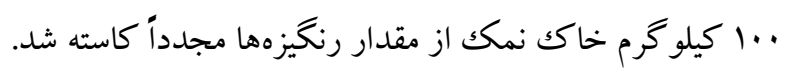
در باب رنغيزهها اختلاف بين كلئ تيمارها در سطح احتمال ها هونه

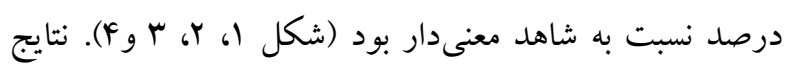

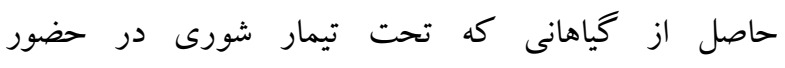

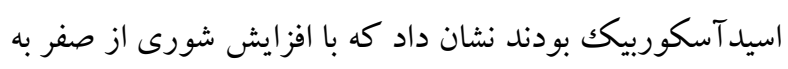




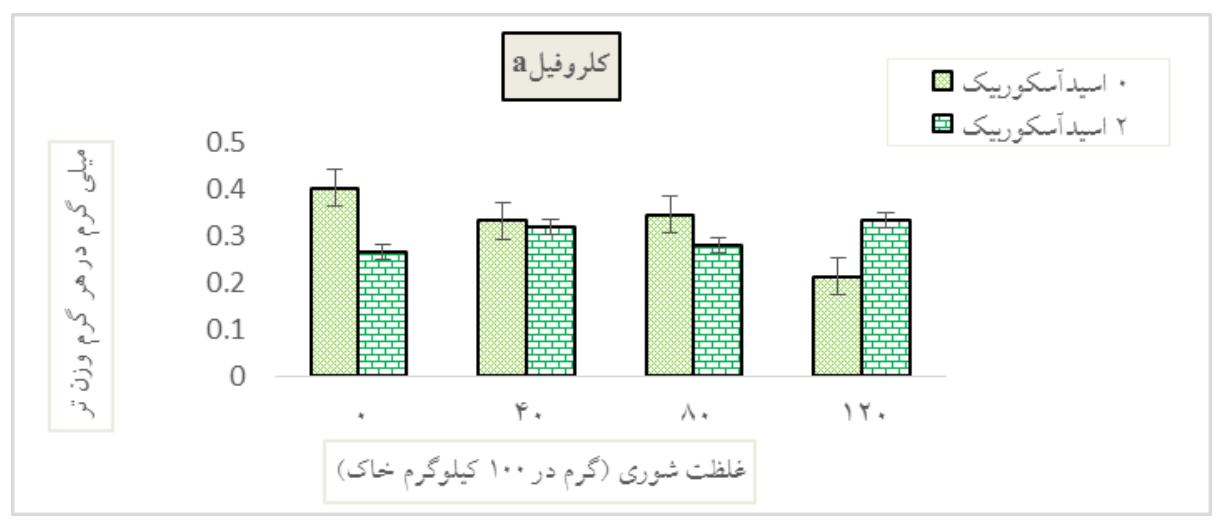

$$
\text { شكل ا- تغييرات مقدار كلروفيل a در غلظتهاى مختلف شورى در حضور و غيبت اسيدآسكوربيك. }
$$

Fig. 1. Alterations in chlorophyll a level at different concentrations of salinity in the presence and absence of ascorbic acid.

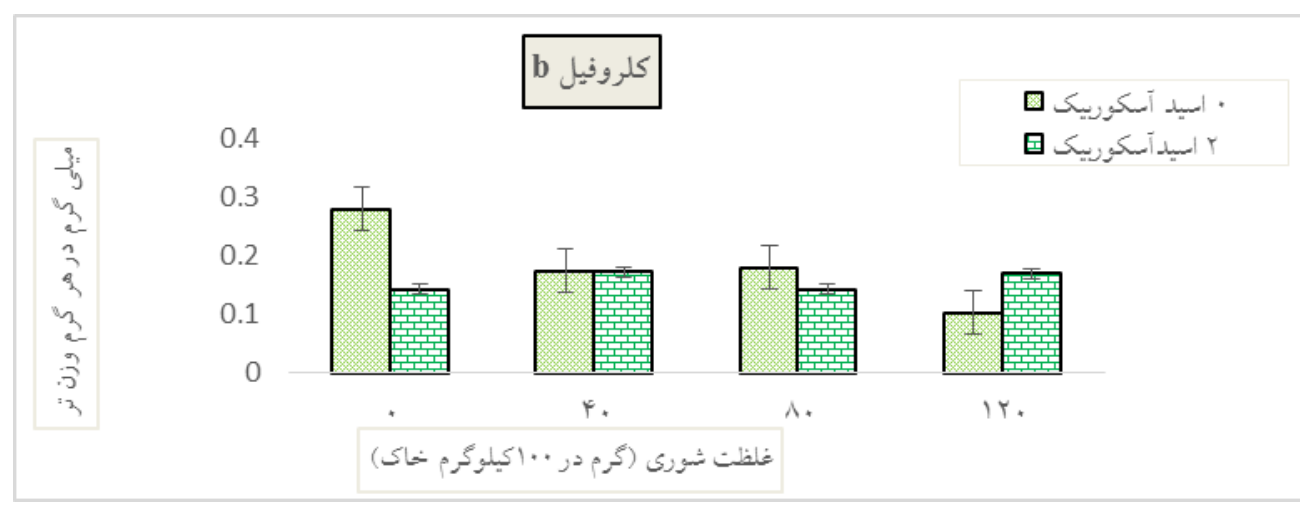

شكل r- تغييرات مقدار كلروفيل b در غلظتهاى مختلف شورى در حضور و غيبت اسيد آسكوربيكك.

Fig. 2. Alterations in chlorophyll b level at different concentrations of salinity in the presence and absence of ascorbic acid.

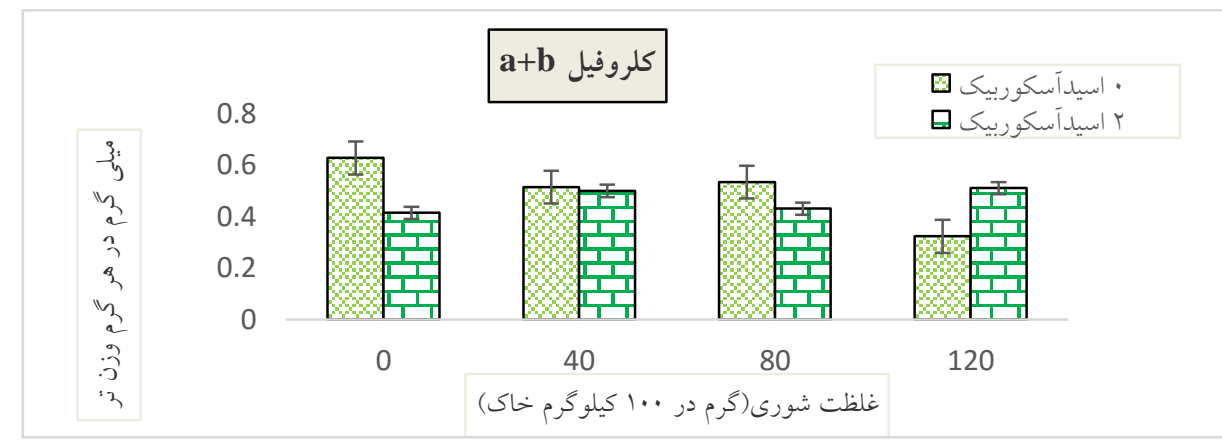

$$
\text { شكلr- تغييرات مقدار كلروفيل a+b در غلظتهاى مختلف شورى در حضور و غيبت اسيد آسكوربيك. }
$$

Fig. 3. Alterations in chlorophyll $a+b$ level at different concentrations of salinity in the presence and absence of ascorbic acid. 


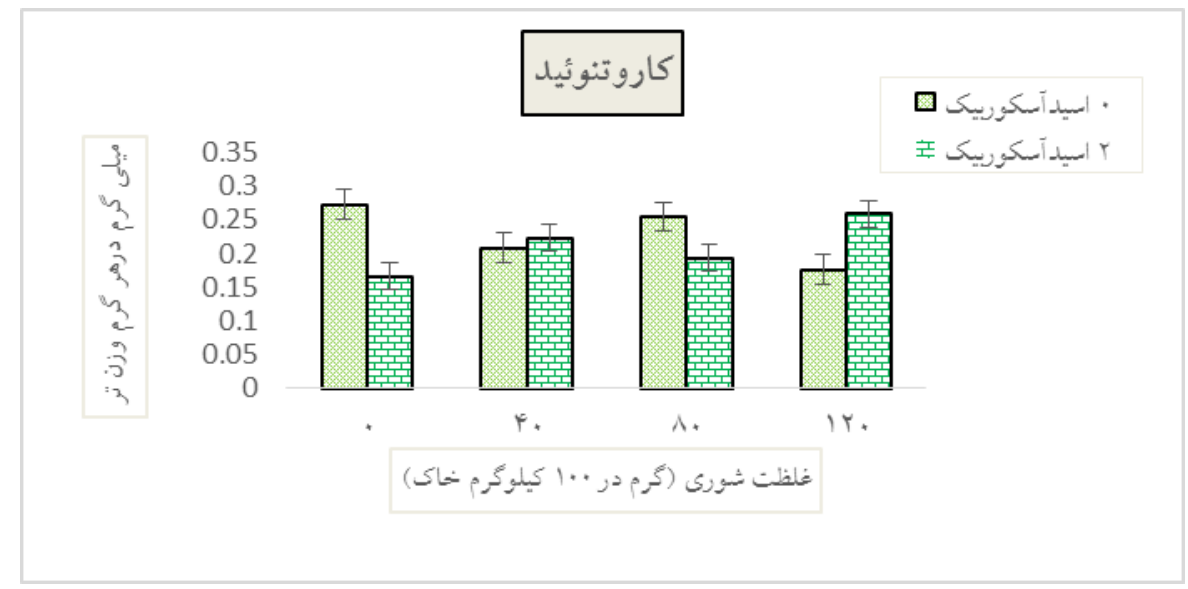

$$
\text { شكل F- تغييرات مقدار كاروتنوئيد در غلظتهاى مختلف شورى در حضور و غيبت اسيد آسكوربيك. }
$$

Fig. 4. Alterations in carotenoid levels at different concentrations of salinity in the presence and absence of ascorbic acid.

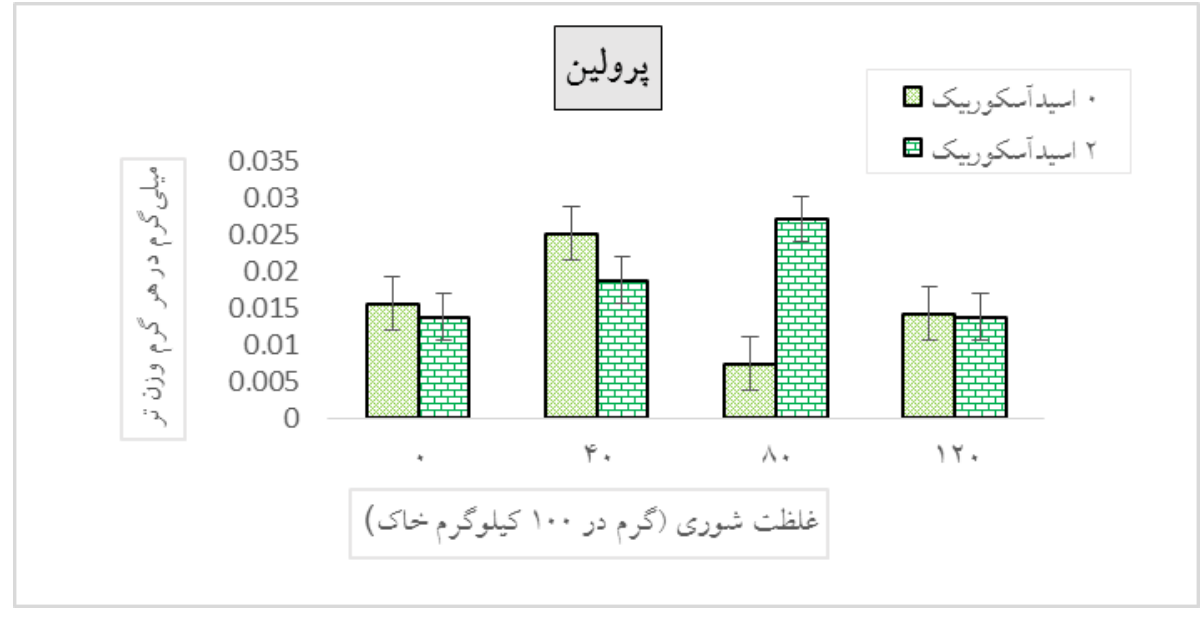

$$
\text { شكل ه- تغييرات مقدار برولين در غلظتهاى مختلف شورى در حضور و غيبت اسيد آسكوربيك. }
$$

Fig. 5. Alterations in proline level at different concentrations of salinity in the presence and absence of ascorbic acid.

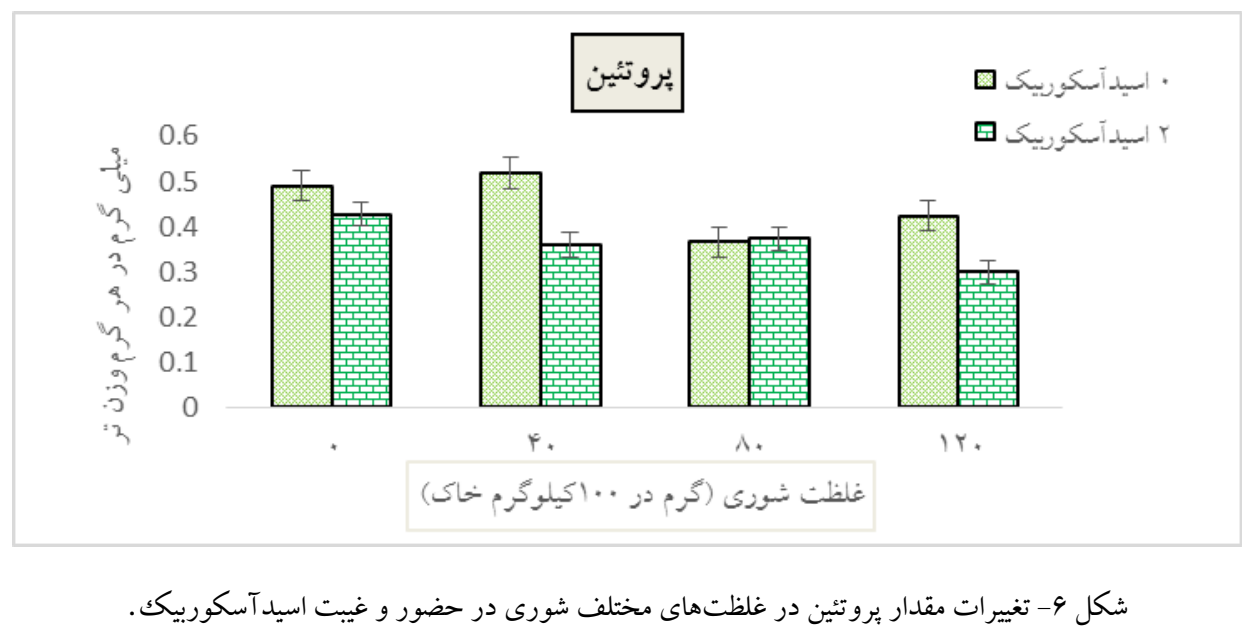

Fig. 6. Alterations in protein levels at different concentrations of salinity in the presence and absence of ascorbic acid. 


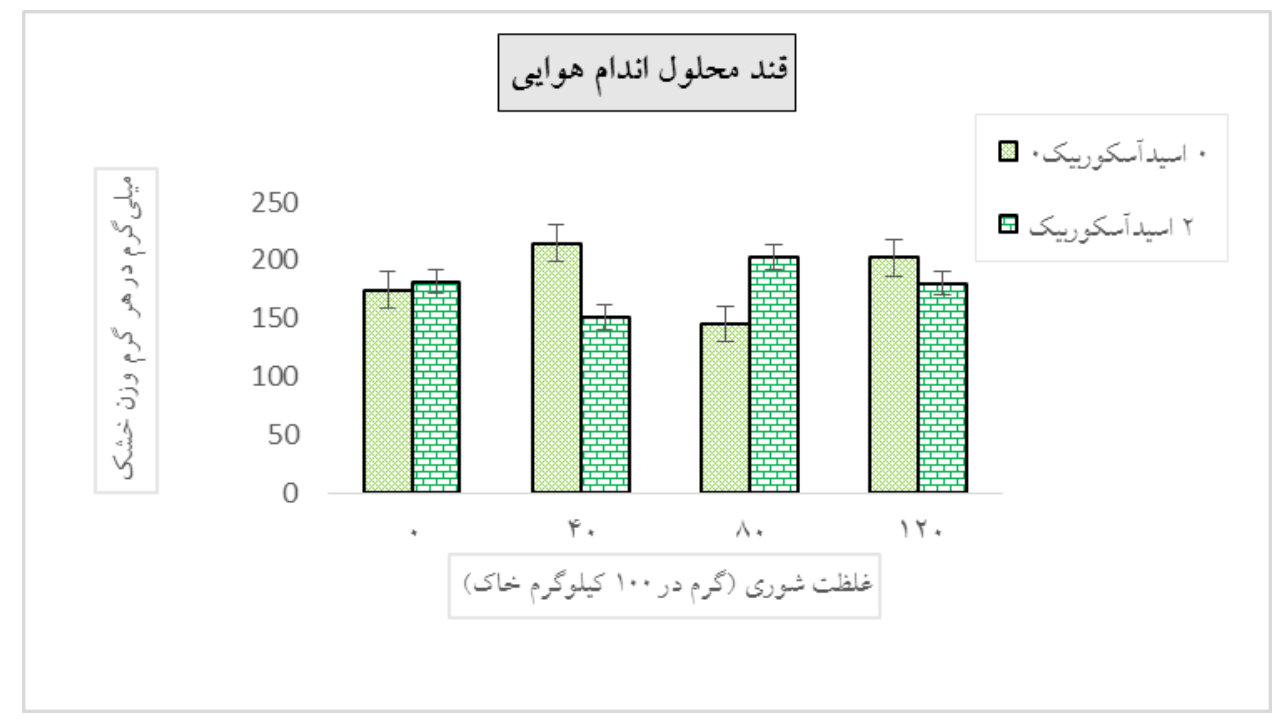

شكل V- تغييرات مقدار قند محلول اندام هو ايى در غلظتهاى مختلف شورى در حضور و غيبت اسيد آسكوربيك

Fig. 7. Alterations in soluble sugar of aerial parts at different concentrations of salinity in the presence and absence of ascorbic acid.

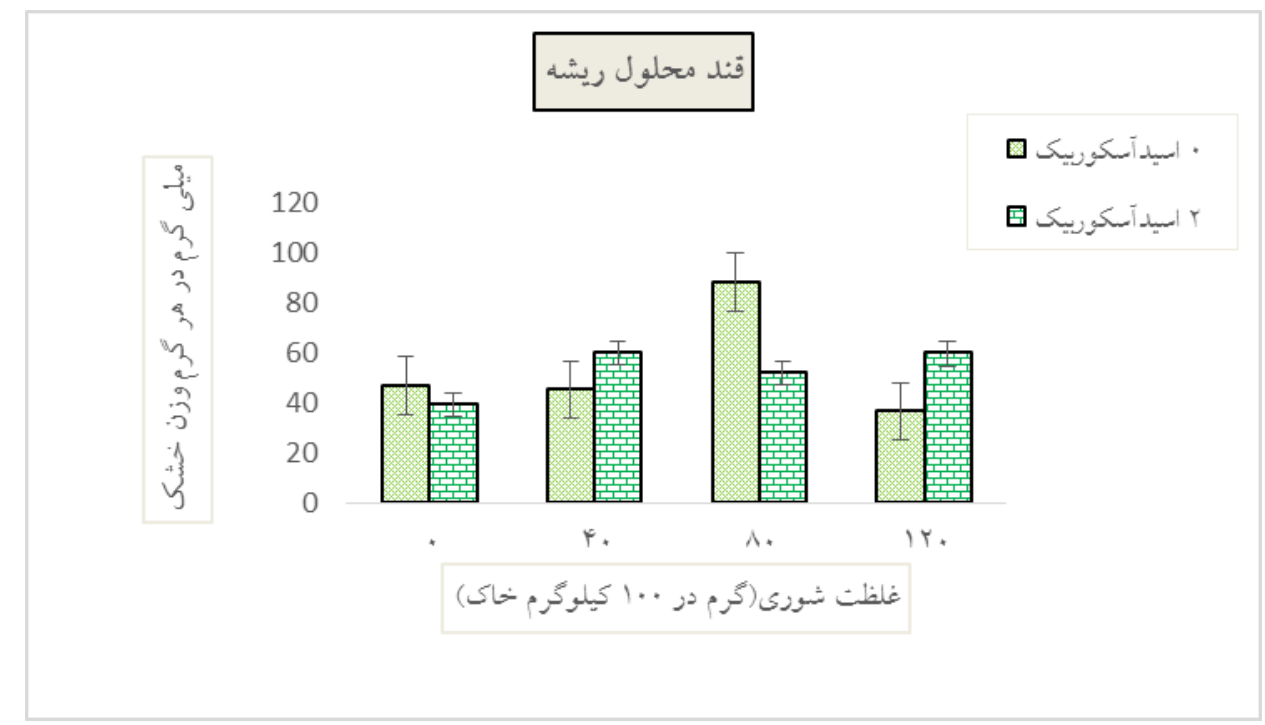

شكل ^- تغييرات قند محلول در غلظتهاى مختلف شورى در حضور و غيبت اسيد آسكوربيك.

Fig. 8. Alterations in soluble sugar at different concentrations of salinity in the presence and absence of ascorbic acid.

اسيدآسكوربيك را مربوط به كاهش زيانهاى ناشى از راديكالهاى آزاد واكنش گر نسبت به ماكرومورلكولهاى زيستى (Noctor \& Foyer, 1998) نو كلئيكاسيدها مىدانند (Inze \&Van Montagu, 1995). جنان كه مشاهده مى شود، در اين مطالعه حفظ محتواى كلروفيل

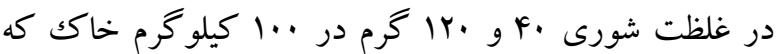
ازطريق تيمار اسيدآسكوربيكك حاصل شده است، به ثبات فتوسنتز در اين وضعيت كمكك مى كند. تيمار اسيدآسكوربيك

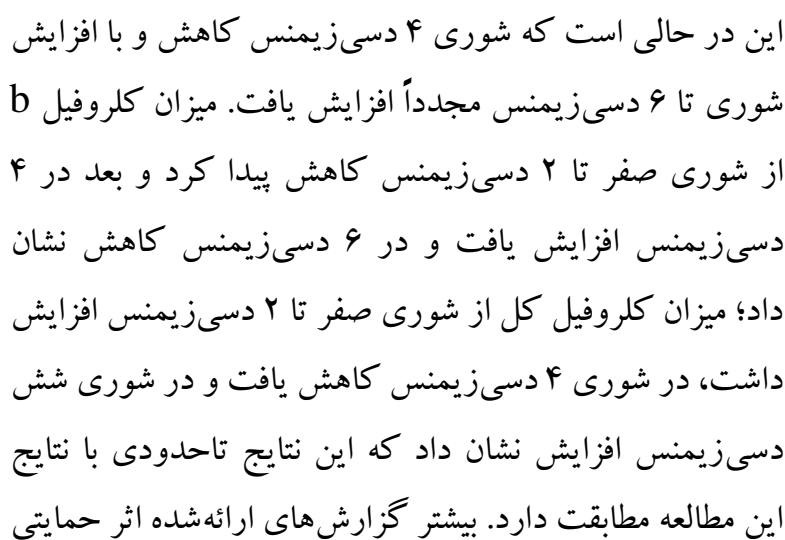

اين در حالى است كه شورى F دسىزيمنس كاهش و با افزايش شورى تا ودسىزيمنس مجدداً افزايش يافت. ميزان كلروفيل از شورى صفر تا Y دسىزيمنس كاهش بيدا كرد و بعد در F دسىزيمنس افزايش يافت و در 9 دسىزيمنس كاهش نشان دسىزيمنس افزايش نشان داد كه اين نتايج تاحدودى با نتايج اين مطالعه مطابقت دارد. بيشتر گزارش هاى ارائه شده اثر حمايتى 


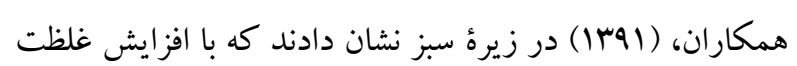
كلريد سديم ميزان برولين در تمام تيمارها نسبت به شاهد افزايش يافت و در غلظتهاى يكسان كلريد سديم تيمارهايى

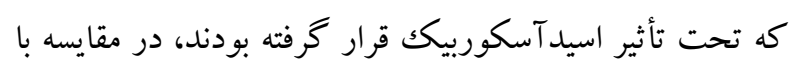
كياهانى كه فقط تحت تأثير كلريدسديم بودند افزايش بيشترى در ميزان يرولين نشان دادند و بيشترين ميزان اسيدآسكوربيك در بيشترين مقدار شورى بود كه با نتايج اين تحقيق مطابقت ندارد.

تجمع يرولين يكى از شاخص هايى است كه با افزايش مقاومت نسبت به كم آبى و شورى ايجادشده در گياهان رابطه مستقيم دارد (Saneoka et al., 2004). تجمع برولين در سيتويلاسم سلول گياهى مانند اسموتيكوم در حفاظت ساختمان ماكرومولكولها در محيطى كه تعادل يونى آن بههم خورده

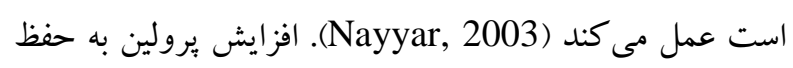
تورم و كاهش خسارت غشا در كياهان منجر مىشود. بدين ترتيب با روش تنظيم اسمزى، ساز كارى به تنش كم آبى و شورى افزايش مىيابد (Pandey \& Agarwal, 1998). قندها سبب تنظيم اسمزى و نيز پيايدارى غشاها و يروتئينهاى موجود

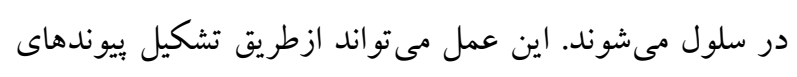
هيدروزنى بين كروههاى كربو كسيل قندها و زنجيرههاى قطبى

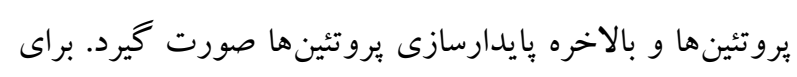
مثال تجمع ساكارز موجب حفظ فسفولييدهاى غشا مى شود و از تغييرات ساختارى در بيروتئينهاى محلول سلول نيز جلو گيرى مى كند. گياهانى كه در تنش شورى حاوى قندهاى محلول بيشترى هستند تحمل شورى بيشترى از خود نشان مى دهند. تغيير

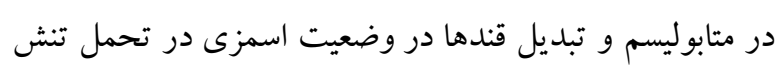
داراى نقش تعيين كنندهاى است. افزايش غلظت قندها، علاوهبر اينكه باعث منفىترشدن يتانسيل اسمزى در سيتويلاسم مى نعى إنى شود، در حفاظت اسمزى غشاها و نيز جاروب كردن راديكالهاى آزاد اكسيزن نيز مى شود (Kerepesi \& Galiba, 2000). اسميرنف معتقد است كه آسكوربيك اسيد بهمثابهُ يكك ملكول كوجّك با توان فيزيولوزيكك بالا مى تواند فر آيند مادهسازى و به ويزه ساخت قندها را در جهتى القا كند كه درنهايت به رشد گياه منجر شود. بهعبارت ديخر، كاهش قندهاى محلول در حضور آسكوربيكك اسيد ممكن است بهدليل افزايش رشد باشد.
از يبامدهاى مخرب تنش بر رشد و محتواى كلروفيل مى كاهد

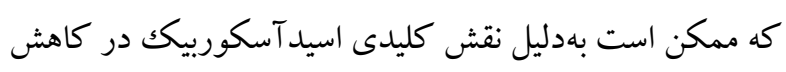
آنتى اكسيدانها باشد.

تنش شورى باعث افزايش راديكالهاى آزاد در كلرويلاستها مىشود و تخريب كلروفيل و غشاى كلرويلاست را دريى دارد.

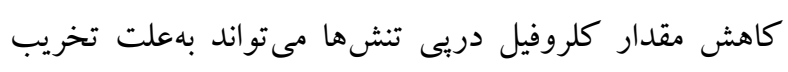

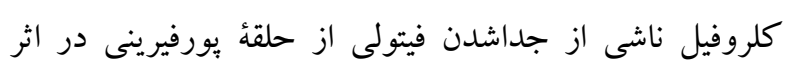
كونهاى فعال اكسيزن يا آنزيم كلروفيلاز باشد. بررسى أنها بيان

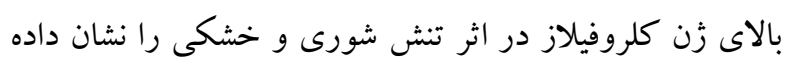

كاهش مقدار كاروتنوئيدها در وضعيت تنش بهدليل تجزئ

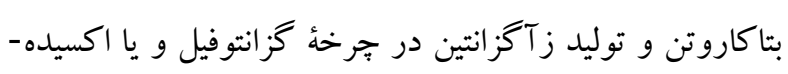

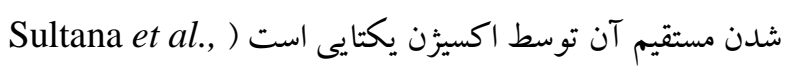

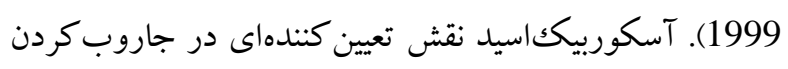

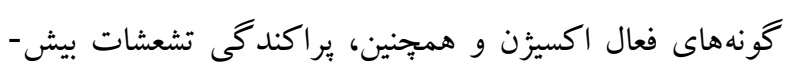

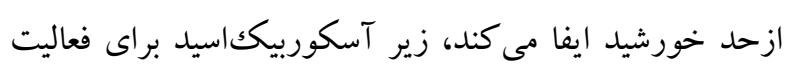

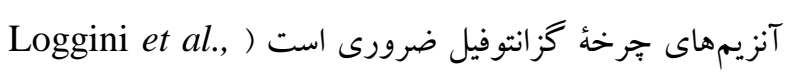

كزارش شده است كه با بررسى كاربرد برونزاى

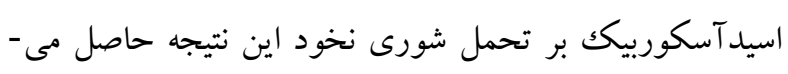

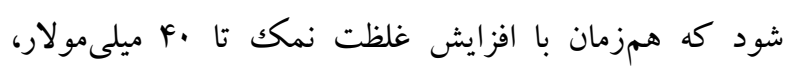

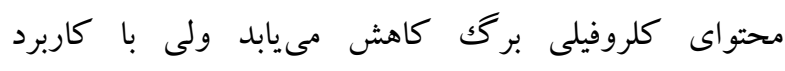

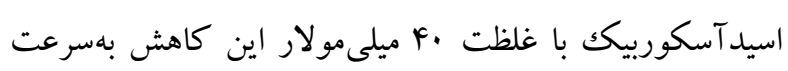

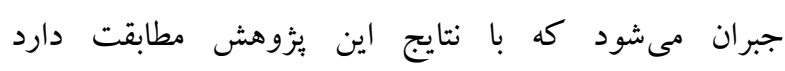

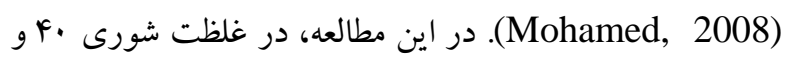

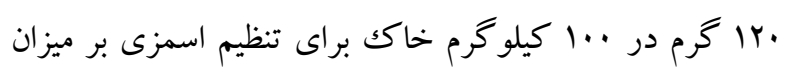

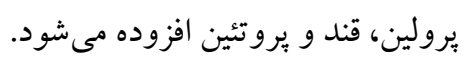

نجفى و همكاران (•l.1.1) نشان دادند كه قند محلول در مرزهة

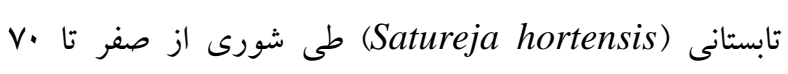

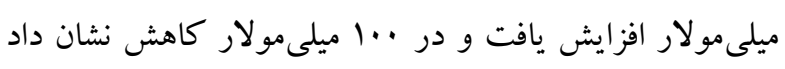

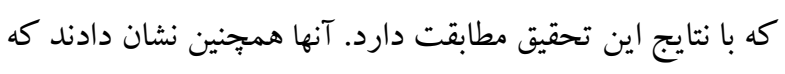
در اين خياه طى تغيير شورى از صفر تا ... إيلى مولار بر مقدار

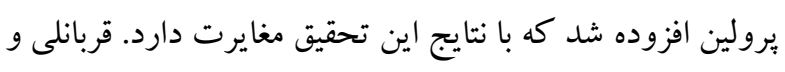


مونوريبوزومها مىشود كه اين مسئله باز گو كنندهُ كاهش سنتز يروتئينها است. در بثزوهش حاضر، استفاده از اسكوربيك اسيد به طور كلى باعث افزايش محتوى بروتئين شد. آسكوربيكاسيد با حذف مستقيم يا غيرمستقيم راديكالهاى آزاد از اكسيدشدن و تخريب ساختارهاى يروتئين ها جلو گيرى مى كند. مشابه نتايج اين تحقيق كاربرد آسكوربيككاسيد خارجى مقدار يروتئين را در كياه سيبزمينى تحت تنش افزايش داده است (دانشمند،

.(Irar

\section{سياسگز ارى}

مؤلفان بدينوسيله مراتب سياس و قدردانى خود را از اعضاء كروه زيست شناسى لرستان و شركت داروسازى خرمان لرستان بابت تأمين نهالهاى مورد استفاده در اين يزٔوهش اعلام مى -

كنند.

قربانلى، م.، ساطعى، آ. و مقيسه، 1.، Y Yrا. اثر شوككهاى مختلف

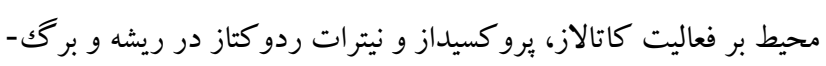
هاى دو رقم كلزا (Brassica napus). يثوهش و سازندگى بـ (1) (1): kr-rq شهبازى، م. و محقق دوست، ز. IFVD. بررسى آثار كلرور سديم بر

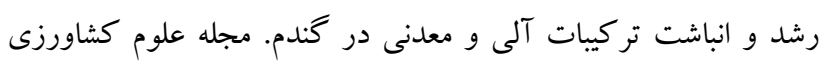
ايران (F) rV)

Akbari, S., Kordi, S., Fatahi, S. and Ghanbari, F., 2013. Physiological responses of summer savory (Satureja hortensis L.) under salinity stress. - Int. J. Agri. Crop. Sci. 5(15): 1702-1708.

Arnon, D.I. 1949. Copper enzymes in isolated chloroplasts. Polyphenoloxidase in Beta vulgaris.

- Plant Physiol. 24(1): 1-15.

Ashraf, M. and Harris, P. 2004. Potential biochemical indicators of salinity tolerance in plants. - Plant Sci. 166(1): 3-16.

$$
\begin{aligned}
& \text { البته اين احتمال وجود دارد كه با كاربرد آسكوربيك اسيد تنش } \\
& \text { كاهش يابد و ضرورت افزايش قندهاى محلول كاهش يافته }
\end{aligned}
$$

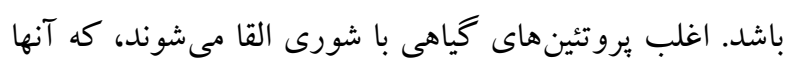

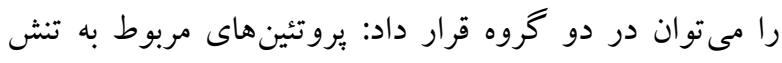

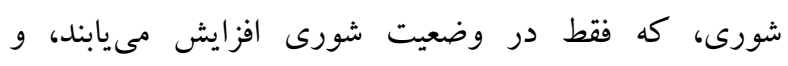

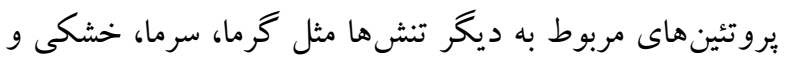

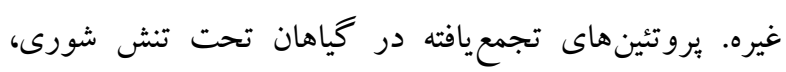

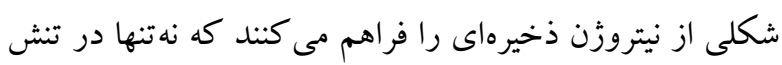

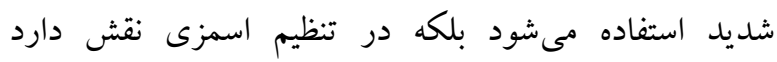

$$
\begin{aligned}
& \text { (Ashraf \& Hariss, 2004) }
\end{aligned}
$$

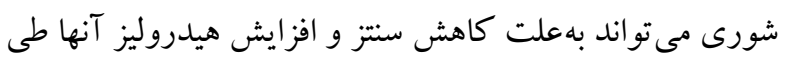

$$
\begin{aligned}
& \text { تنش باشد. تنش كم آبى سبب تخريب ساختار يروتئينها و و }
\end{aligned}
$$

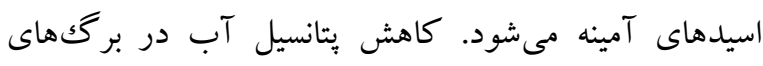

$$
\begin{aligned}
& \text { ذرت، موجب نقصان درخور توجهى در يلىريبوزومها و }
\end{aligned}
$$

منابع / References

$$
\begin{aligned}
& \text { دانشمند، ف. זوبا. اثر بي تيمار آسكوربيككاسيد در گياه گوجه- } \\
& \text { فرنخى و واكنش به تنش خشكى ميزان تنش اكسيداتيو، اسموليتها، }
\end{aligned}
$$

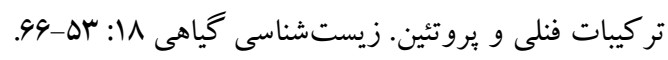

عصرى، ى.، ومبا. جغرافياى گياهى. انتشارات دانشكاه بيام نور، تهران.

Yr

Bates, L., Waldren, R. and Teare, I. 1973. Rapid determination of free proline for waterstress studies. - Plant soil 39(1): 205-207.

Bradford, K.J. and Hsiao, T.C. 1982. Physiological response to moderate water stress. In: Physiological Plant Ecology. II. Water relation and carbon assimilation Encyclopedia Plant physiques, Vol. 123, eds Laneg, O.L., Nobel, P. S., Osmond, C. B. and Zeigler, Z, Springer Vellage, Berlin and New York. pp. 263-324.

Colom, M. and Vazzana, C. 2001. Drought stress effects on three cultivars of Eragrostis 
curvula: photosynthesis and water relations. Plant Growth Regul. 34(2): 195-202.

Farsam, H., Amanlou, M., Radpour, M., Salehinia, A. and Shafiee, A. 2004. Composition of the essential oils of wild and cultivated Satureja khuzistanica Jamzad from Iran. Flavour Frag. J. 19(4): 308-310.

Huang, C., He, W., Guo, J., Chang, X., Su, P. and Zhang, L. 2005. Increased sensitivity to salt stress in an ascorbate-deficient Arabidopsis mutant. - J. Exp. Bot. 56(422): 3041-3049.

Inze, D. and Montagu, M.V. 1995. Oxidative stress in plants. - Curr. Opin. Biotech. 6(2): 153158.

Jamzad, Z. 1994. A new species of the genus Satureja (Labiatae) from Iran. - Iranian J. Bot. 6(2): 215-218.

Jones, J. B. 1983. A Guide for the Hydroponic and Soilless Culture Grower.Timber Press, 124 p.302-312.

Kerepesi, I. and Galiba, G. 2000. Osmotic and salt stress induced alternation in solute carbohydrate content in wheat seedlings. - Crop Sci. 40: 482-487.

Kochert, G. 1978. Carbohydrate determination by the phenol-sulfuric acid method. Handbook of phycological methods 2: 95-97.

Lichtenthaler, H.K. 1987. Chlorophylls and carotenoids: pigments of photosynthetic biomembranes. - Meth. Enzymol. 148: 350-382.

Loggini, B., Scartazza, A., Brugonli, E. and Navari-Izzo, F. 1999. Antioxidative defense system, pigment composition and photosynthetic efficiency in two wheat cultivars subjected to drought. - Plant Physiol. 119: 1091-1099.

Mohamed, S. B. 2008. Exogenous ascorbic acid (vitamin C) induced anabolic changes for salt tolerance in chick pea (Cicer arietinum L.) plants. - Afr. J. Plant Sci. 2(10): 118-123.
Munns, R., James, R. A. and Lauchli, A. 2006. Approaches to increasing the salt tolerance of wheat and other cereals. - J. Exp. Bot. 57(5): 1025-1043.

Najafi, F., Khavari-Nejad, R. and Ali, M. S. 2010. The effects of salt stress on certain physiological parameters in summer savory (Satureja hortensis L.) plants. - J. Stress physiol. Biochem. 6(1): 13-21.

Nayyar, H. 2003. Accumulation of osmolytes and osmotic adjustment in water-stressed wheat (Triticum aestivum) and maize (Zea mays) as affected by calcium and its antagonists. Environ. Exper. Bot. 50(3): 253-264.

Noctor, G. and Foyer, C.H. 1998. Ascorbate and glutathione: keeping active oxygen under control. - Annu. Rev.Plant Biol. 49(1): 249-279.

Pandey, R. and Agarwal, R. 1998. Water stressinduced changes in proline contents and nitrate reductase activity in rice under light and dark conditions. - Physiol. Mol. Biol. Plants. 4: 53-57.

Parida, A. K. and Das, A.B. 2005. Salt tolerance and salinity effects on plants: a review. - Ecotox. Environ. Safe. 60(3): 324-349.

Saneoka, H., Moghaieb, R.E., Premachandra, G.S. and Fujita, K. 2004. Nitrogen nutrition and water stress effects on cell membrane stability and leaf water relations in Agrostis palustris Huds. Environ. Exp. Bot. 52(2): 131-138.

Silva, C., Martinez, V. and Carvajal, M. 2008. Osmotic versus toxic effects of $\mathrm{NaCl}$ on pepper plants. - Biol. Plantarum 52(1): 72-79.

Smirnoff, N. 2000. Ascorbic acid, metabolism and function of a multi-facetted molecule. Curr. Opin. Plant Biol. 3: 229-235.

Sultana, N., Ikeda, T. and Itoh. R. 1999. Effect of $\mathrm{NaCl}$ salinity on photosynthesis and dry matter accumulation in developing rice grains. Environ. Exp. Bot. 42(3): 211-220. 
Van Breusegem, F., Vranova, E., Dat, J.F. and Inze, D. 2001. The role of active oxygen species in plant signal transduction. - Plant Sci. 161(3): 405-414.
Wagner, H., Wierer, M. and Bauer, R. 1986. In vitro inhibition of prostaglandin biosynthesis by essential oils and phenolic compounds. - Planta Med. (3): 184-187.

******

Amiri, H. and Moazzeni, L. 2016. Interaction of salinity and ascorbic acid with some biochemical features in Satureja khuzestanica. - Nova Biol. Rep. 3(1): 69-79.

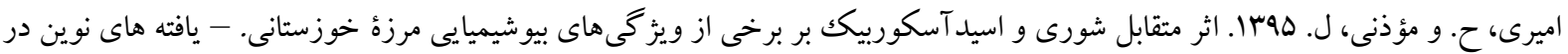

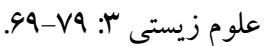

